\title{
ADVISERS TO MINISTERS IN TURKISH PUBLIC ADMINISTRATION*
}

\author{
Özden AKIN ${ }^{* *}$
}

\section{INTRODUCTION}

Access to multiple and discrete sources of advice has been increasingly in demand by both private and public sector organizations in recent years as the result of the rapid technological change, economic and social imperatives. As a result of this trend, concepts of advice and adviser has become the actual subjects on which there are a plenty of discussions.

Considering the simple meaning of advice as to inform someone, an advising relationship can be realized even in the case someone ask the idea of a friend. If the advice is perceived as a form of relationship, main elements involved can be regarded as the sides in the relation as well as the context of the relationship is established. When we receive the context of the relationship as an organization, the basic question in the phenomenon of advice is to understand who on the side of giving advice is as well as who on the side of demanding advice stands. This, in fact, explains the main idea behind what we want to do in this study. In other words, we will try to investigate who is on the side of adviser in the context of our administrative system when the political executives stand on the side of the advisee.

We can say that, as well as the universal actuality of the issue, the widespread use of advisers in the governmental organizations as a current problem of Turkish administrative system that has been subjected to the various criticisms and discussions has motivated us to realize this study. This complies with the well-known reality that the basic incentive pushing the researchers to search answers for the questions born to their mind is the mystery of the unknown. It would not be false to say that the issue of advisory services is an area of problem in our administrative system left "unknown" because of the limited number of studies dealing with it. In our opinion, this is the other

\footnotetext{
* This study is a revised part of the master's thesis written out by the author.

** Research Assistant at Faculty of Political Sciences in Ankara University.
} 
major reason explaining the significance of the study besides the actuality of the problem.

Another major question was to determine the scope of the sudy. We have known that we must be careful in determining limitations since the issue has many aspects that can be widely examined. Then we determined that the focus of our study would be the practice of personal advising to the political executives in governmental organizations since through our survey on the literature we observed that this is the most outstanding example of the trend to hire advisers in the practice around the world. As parallel to it, we also observed that the subject of the discussions and criticisms relevant to practice in our country has mostly been focused on the same direction.

In this context, the examination of the practice of personal advising to the political executives in Turkish public administration was the primary limitation within the conceptual frame of our study. Then, the emphasis of the study was placed on the descriptive analysis and evaluation on the advisers to top political executives in the central organization of Prime Ministry and of ministries through an empirical research. This empirical research was structured within the insights from the conceptual framework that will be examined in detail as the main subject of this paper. We considered the part of the empirical research and the analysis of its findings out of the scope of this paper but it is useful to summarize what we did through this research.

By the aim of a descriptive study; personal qualifications, functions, work pattern of advisers and some problems advisers face were the main subjects that were analyzed by various dimensions. The method of data collection employed in this research was the questionnaire survey. It was conducted on the advisers who are direculy placed under the authority of the ministers and Prime Minister in the central organization of Prime Ministry and of twelve ministries. Taking the conditions of the practice in Turkey into consideration, advisers were classified into two subgroups as Müsavirs and Special Advisers and this was kept in view in the evaluation of the research findings.

Leaving further details on the methodology of the research, in this paper we will focus on the conceptual framework of our study. In search of this conceptual framework, it was the organization theory that primarily guides the study and within its insights adviser was described in general terms as a staff. That's why, in the first part of the paper we will examine adviser as an organizational phenomenon by analyzing the concept of staff through the theories of organization. The evaluation of some dynamics behind the access to advisers by the political executives will be the subject of second part of the paper. The discussion of some fundamental issues concerning advisers with the focus of the different advisory systems and a brief review of the practice in Turkey will be realized in the subsequent parts of the study.

\section{1. "ADVISER" AS AN ORGANIZATIONAL PHENOMENON: CONCEPT OF STAFF}

\subsection{Staff in Organization: A Review on the Theories of Organization}

At the beginning of the 20th Century, Classical Organization Theorists established their conception of the organizational functions on the distinction of the two 
structures: line and staff. Rising importance of different skills and knowledge in the complicated tasks of decision makers had caused the need for them to apply the specialized knowledge of the experts. Variety of the activities and skills necessitates a new structure of the organization that must be convenient to the ultimate ideal of "rational decision making."

They believed that the only way to use expertise in a most efficient way to realize rational decisions is to distinguish it from decision process by putting the experts in a status where the only function of them would be to provide necessary knowledge and solutions for the problems of the decision makers.

Urwick, one of the famous classical theorists, argues that the principle of line/ staff separation is essential for the formal organization. In his detailed analysis of the "staff" concept, he states that "any function which is specialized may apparently becomes a staff function," illustrating functions of the staff as follows (1937: 58):

“...gives expert advice to the line officers. making ...are engaged in the business of analyzing, testing comparing, recording, researches, coordinating information and advising.

...furnish the means of developing standards and plans.

...gives special types of services.

...is responsible for investigations, study and designing...."

It is emphasized that the relation of the staff to the other departments is advisory in its character. Mooney perceives that staff function has a supervisory phase other than informative and advisory phases. Its functions as informative and advisory in planning and becomes supervisory in the execution of plans. Giving Ancient examples of Homeric chiefs whose counseling is important for the king, and witenagemor that is the council of wise men having literacy, he argues that staff with the functions attributed to them are the extension of the personality of the executive and mean more eyes, more ears, more hands to aid him in forming and carrying out all his plans (Mooney, 1947:34).

Classical organization theory gives a great importance to the principles of hierarchy and unity of command and is strict in seperating staff function from the line that commits to the hierarchical authority. Gulick points out that staff are those persons who devote their time exclusively knowing , thinking and planning functions separated from the line that is concerned with the doing of the functions. He stresses that staff do not issue command and do not take responsibility and states that (Gulick, 1937:32);

".... when administrative responsibility and power added to any staff function, that function becomes immediately and completely a line function. There is no middle ground."

Fayol discusses the concept of staff in governmental organizations. He indicates the necessity of staff for the executive organs like prime ministry, ministry and directions of them, including a secretariat, consultants and accountants to assist them in carrying out their duties. He makes another classification of staff function in the form of councils for improvements, whose function is carried out under planning, organization, command, coordination units as advisory and informative organs (Fayol,1937:109-111). 
A similar suggestion of staff function is made by Stone in the form of the budgeting, program, planning, personnel and methods planning divisions. He describes the functions of these divisions as follows (Stone, 1953:352):

"...Providing a source of highest counsel and advice on matters about which the executive is uncertain or has reason to doubt to solution offered by an operating subordinate.

...Providing the means of gathering information and of securing understanding and accepting of policy, mapping out policy and program, working out fundamental organization and methods...."

In his idea, as parallel to the formers, staff must stay in the role of advising, consulting and coordinating; must avoid their personal judgment on line officers on operating matters. Otherwise, it becomes a burden rather than help if they diffuse the executive"s line of command.

A basic classification of functions of staff is generally observed within the approach of Classical theory, defining them in two forms: one providing support based on technical expertise and the other providing auxiliary services. Urwick indicates that this division mostly creates a problem of terminology in explaining staff concept that is admittedly borrowed from the military organization. In the military organization, there is a distinction between general staff officers who assist the commander in carrying out his functions of command and technical and administrative staff officers who assist the commander on an advisory capacity in matters pertaining to their special branches. While the former performs rather coordinative duties, the latter performs specialized technical services. Urwick indicates that the difficulty is mostly experienced in understanding of the place of General Staff or Staff Officers in civilian organizations as the terms inherited from the terminology of military organization. For this reason, he had made the corresponding definitions for the practice of civilian organizations as we would investigate later. ( 1937:61).

Simon and others explains this distinction like that staff units assist the administrator in performing duties line units would not perform in the absence of them while auxiliary staff units perform some common duties line units need. (1985:221)

It is argued by some authors that the most realistic description of personal staff assistance is made by Urwick. Self, as one of them, indicates that other Classical writers analyze staff asistance in terms of institutionalized forms as it is in the Gulick or POSDCORB sense and criticizes this approach saying that as much as staff assistance is institutionalized it becomes far from being personal assistance and from being "extension of the chief's persona," since the institutionalized staff units perform duties in the chief's name and his formal authority but resting upon organizational rules and conventions rather than personal wishes of the chief himself. This is not different from what line units do, then, it is not meaningful to state them as the extension of the chiefís persona (Self, 1977:123).

Neoclassical School that gained the dominance by the end of the World War II, criticizing the approach of the Classical School with the principal argument that it 
ignores the behavioral aspects and the problems related to the human relations in the organization and brings a different comment on the staff concept especially in terms of authority.

Herbert Simon, one of the most influential Neoclassical writers, argues that the principles like unity of command and hierarchy that were given great importance by the Classical School, are conflicting and inconsistent with the principle of specialization. To gain the advantages of the specialized skill, the work of the organization must be subdivided in a manner enabling a particular skill can be performed by the personnel possessing that skill. (Simon,1957:10) Likewise, to gain the advantages of expertise in decision making, the responsibilities of decisions must be so allocated that all decisions requiring a particular skill can be given by persons possessing that skill. He expresses his view in his own words as follows:

"...So long as the communication of decisions is restricted to the formal hierarchy of authority, it is not possible to secure the several kinds of technical asistance that are needed for a single decision. To secure all the advantages, therefore, of expertise in decision making, it is necessary to go beyond the formal structure of authority. The authority of ideas must gain an importance in the organization coordinated with the authority of sanctions(1957:136)."

As consequent to his above ideas, Simon brings the concept of functional authority that enables staff to exercise authority in making decisions at least in the areas of their expertise. This is an important stage in the evolution of staff concept from the earliest rigid definitions to contemporary flexible practices that would find its most extreme form in the phenomenon of advice as we would see later.

Mary Parker Follett, another neoclassical author, furthers Simon's idea claiming that the expert's information not only forms a large part of the executive decision, it is an integral part of the decision making machinery and adds (1964:225)

"...The seperation between advice and decision can not be a rigid one, since pure information is seldom given by expert to executive. Most experts both interpret facts and relate them to the decisions..."

Follett indicates, even if expert's advice is not allowed automatically to become a decision, the importance of this advice is great and what remains to a leader is to coordinate, unite these ideas and to transform them into a power to realize the ultimate purpose (in Metcalf, 1964:48).

As observed in these criticisms, increasing importance of expert knowledge as parallel to the scientific and technological developments, traditional hierarchical structures of the organizations had created problems in fitting new developments to the older definitions of role.

Thompson defined the problem of the modern organization as the growing gap between the "authority to do" that is right to decide and the "power to do" which is specialized ability. The growing imbalance between ability and authority is the most symptomatic characteristic of the bureaucracy, in Thompson's view, this imbalance has been becoming more and more difficult to be got rid of since technology with the result 
of increasing specialization changes faster than in traditional role definitions of the hierarchical framework. Specialties in staff win authority of a non-hierarchical kind that invades the domain of the hierarchical authority of line. The only way to reduce the tension , he suggests, to let the staff participate in decision making (Thompson, 1964: 67, 102).

As parallel to the increasing discussions on line - staff relations and conflicts, these problems have started to be subject to the empirical researches that investigate the sociological and social psychological differences between two groups.

Dalton's study, as an example, contains a detailed analysis of line and staff based on his findings derived from a research conducted in a factory. Conflicts are referred to the attitude differences of two groups stemmed from the differences in terms of education, age, social and professional backgrounds and solutions to these problems are suggested (Dalton, 1959: 71-109).

In the findings of Dalton, general characteristics of staff is defined as welleducated, younger, more tended to the autonomous and scientific based studying, more committed to the professional standards whereas line are more committed to the organizational objectives and rules, more experienced in occupational background, more resistant to change.

If we summarize the viewpoints of the Classical and Neoclassical School on the issue, despite some differences in approaches of the two school it can be argued that both adopt the separation of staff from the line and subordination of the staff to the hierarchical authority of the line even if they have functional authority referring to the limited jurisdiction on specialized areas of the work. Rationality is the ultimate ideal in the organizational model of both schools with the differences in measures to reach it. The problem is to use expert knowledge in realizing rationality without destroying the other principles of administration like hierarchical authority and unity of command. Classical School tries to do it through strict separation of staff officials having expert knowledge from the line in terms of functions and authority on decisions. Neoclassical school emphasizes the right of the staff to participate in decisions with the functional authority without underestimating the maintenance of other principles, even if it criticizes strict approach of Classical school.

When we examined modern theories of organization, some differentiation in the perception of the roles defined by the previous approaches as parallel to the changing, view of the organization. System Approach, as one of the most important modern theories, views the organization as a complex set of interconnected elements including its inputs, processes, outputs, feedback mechanisms and the environment in which it operates. Unlike to the Classical and Neoclassical School viewing organizations as static structures operating in a stable, machine-like order, the system school sees organizations as dynamic processes of interactions among organizational elements and as adaptive systems that must adjust to changes in their environment to survive.

In parallel to their different perception of organization, system approach shows some differences in defining intraorganizational structures. Katz and Kahn describe the functioning of organization with respect to basic intertwined subsystems grouped as production, supportive, maintenance, adaptive and managerial subsystems. Each has 
interrelated functions in the different stages of transformation process of inputs to outputs. Some activities of research and development, planning staff are regarded as involved in the adaptive subsystem enabling organization to comply with a changing environment by providing necessary information. (Katz and Kahn, 1966:42). They interact with the environment of the organization, gather and analyze necessary information, submit proposals on what changes are necessary for the organization to adapt to the environment.

Contingency view of organization that is regarded as close of system theory place high importance on rapid, accurate information systems in increasing organizational effectiveness. Jay Galbraith, as a contingency theorist, argues that uncertainty is one of the problems of the organizations in reaching effectiveness, defined as the difference between the amount of information an organization need and the amount of information it possess. (1973:5). He proposes some measures to avoid both the lack and excessive amount of information in the organization. In his proposals, each unit in the organization should process mecessary information and use it in the decisions of its own.

In this model, increase in the number of experts who can process information and decide concerning the problems of the unit without making unnecessary referral of the information to upward units. This can be regarded as a parallel approach to that of Simon in terms of authority.Galbraith points out that the problem of coordination between these units having authority to make their own decisions but it can be solved by creating integrative positions. He proposes the matrix organization as a model to realize effectiveness in the organization by using information properly as well as maintaining coordination ( Galbraith:1973:93).

To sum up, the main function of expert staff is again providing information, but this time as an "input in the transformation process" in the System and Contingency views. Meanwhile it is also observed that expert staff has been assumed as more interacting with the environment of the organization as well as more influencing in the decision process.

In the later studies on organization, discussions on the staff concept in terms of roles and intraorganizational relations have continued. Nevertheless, blurring in the distinction of line -staff is observed in terms of the both skills and authority relations in the views of contemporary discussions. As Plant argues that "knowledge is power" in the relations of the modem organizations, it doesn't matter whether they are line or staff for the members of the organization having knowledge that is the actual base of the power. (1983:214.)

Longenecker explains this situation as the existence of "line within staff" and "staff within line". It means that staff managers have staff authority in relation to entire organization but line authority from the point of their own staff department, they have direct command over members of the staff unit. Meanwhile line manager can act in a staff capacity as it is in the example in which the head of a production department may act as the general manageris adviser (Longenecker, 1969).

On the other hand, analysis of staff functions and relations by being inspired from Classical Theory's classifications are not rare among contemporary studies. This indicates 
the continuing influence of Classical theory, as the founding father of the concepts as the tools of analysis. We can give the study of Mintzberg as an example.

Mintzberg divides the functions of staff into two as "support staff" and "technostructure" as similar to the auxiliary and technical staff divisions of Classical Organization Theory in some way. Support staff have more traditional functions like legal counsel, public relations whereas technostructure are composed of strategic planners, controllers, personnel trainers, operation researchers, production schedulers. The latter, in Mintzbergís terms, are highly specialized and their functions are based on analysis and standardization. To illustrate, work study analysists like industrial engineers standardize work process, control analysists like budget analysists and accountants standardize outputs and personnel analysists like trainers and recruiters standardize skills. (Mintzberg, 1983: 215).

It is clearly observed that the concept of staff has been subjected to the changes from its original suggestion by Classical Organization Theory even if its influence in analysis has been continuing to some extent. When we look at the discussions, we observe the evolution of staff function in the organizations from its first appearance in the formal organization with a passive image whose only function is to help the decision maker through presenting their knowledge, to the complicated and proliferated types of staff functions whose authority coming from expertise has not been further denied.

We know that increasing amount of information and expertise results in growing difficulty in providing necessary knowledge with traditional role structures in organizations as reflected in the evolution of staff in terms of functions and authority relations. These developments do not only create the changes in the roles but also caused the concept of advice becomes a special phenomenon that exceeds being just a "function" of staff officials in the organizations. The countless fields of expertise as the result of technological developments transformed the status of experts that mostly serve as staff officials in organizations, from the early defined status without authority relevant to their knowledge other than giving it to decision makers to the status of possessors of knowledge who can use it wherever it is requested in the form of advice as independent from limitations on time and place.

So the questions born into the mind about the phenomenon of advice that makes sense as an abstract, uncertain concept. Leaving further analysis of the concept to the subsequent parts of our study, we find it necessary to investigate the staff that serve as the personal assistant of the administrator named as assistant to by some of the writers, before ending the discussion on the staff concept.

\subsection{Staff as Assistant to}

We did a review on the evolution of concept of staff as the origin of advice as an organizational phenomenon through the different viewpoints of the writers on organization, in terms of roles, functions and intraorganizational relations. We did it to understand the organizational dynamics behind the concepts of advice and adviser that are primarily and generally regarded as staff officials in terms of organizational status and functioning. 
This was important to understand staff concept as the basic ground for the concept of adviser in the organizational context. On the other hand, it is also important for our study to understand the logic of staff service presented as individual service to a specific person since our subject is focused on personal advisers.

Rolf and McIntire point out that staff services are categorized according to the criteria to whom they serve as well as their activities. (1983:97). According to this criteria, they make a classification of staff officials in two groups as specialized staff and assistant to type of staff.

From their point of view, in the classification they made according to this criteria "specialized staff" like legal advisers and task accountants serves the entire organization or a large section of it.

On the other hand, the other type of staff is an 'assistant to' who is a personal asistant who may be a generalist or a specialist with typical functions of reviewing, summarizing, interpreting, reporting, carrying out investigations, analyzing problems and recommending solutions.(Rolf and Mc Intire, 1983:98-100).

Authors indicate that this type of staff is frequently used in the organizations characterized by high executive mobility and in the large organizations with great diversity in the units. Government and military organizations are the examples where the executive tend to use personal assistants.

It can be argued that this classification has its origin in Urwick's approach again. As mentioned, he divided staff function into two as technical and administrative staff that is specialized staff who give advice pertaining their own specialties, and as staff officers distinct from both specialized staff and line officers who perform coordinative duties or served in a liaison capacity between their chief and various officials. Urwick states that the latter is a special function requiring definition in each case giving the position of an Executive Assistant or a Private Secretary who functions rather as a personal assistant (1937:75).

We have mentioned that, among the others conducting studies on organizations, Urwick is the author who dwelled on this subject making a detailed description of personal staff assistance. As parallel to his interest, in Staff in Organization (1960) which is a joint work with Ernest Dale he had attempted to make a comparative analysis of assistant to in three types of organization that are military, business and Presidential Organization in US.

In their analysis, Urwick and Dale argue that the primary motive for any kind of executive to have an assistant to is their difficulty to cope with multidimensional burdens on them. ${ }^{1}$ They indicated the difficulty in classifying the functions of an assistant to since it has a unique nature which is open to be redefined and reshaped in each case. In their argument, the most general and the simplest definition of an assistant to's functions as "an extension of his chief's personality" is to worry about the problems which worry

\footnotetext{
${ }^{1}$ We benefit from the above mentioned book of Urwick\&Dale to a great extent in writing this part.
} 
the chief and to do jobs chief can not delegate to any other department or person than his closest aides (Urwick\&Dale, 1960:50-51).

In this context an assistant to has role in a broad range of activities from the ones equivalent to an office secretary's to the ones of a vice presidential nature. At this point we remember the definition of Rolf and McIntire indicating that they are generalist as well as specialist differing from the common practice of staff mostly perceived as stacked to their own specialties at their work (1983:98-100).

If we turn back to Urwick and Dale's analysis of assistant to, we see that they attempt to examine the issue in a systematic way in terms of the functions despite their expression on the difficulty to make unique classifications and analysis by function. In accordance with this attempt, they try to develop a work description of an assistant to as parallel to the executive's functions and divide it into two; one group is related to the "leading" functions of the executive and the other is related to "administrative" functions.

According to this classification, leading functions of an executive include representation, initiation, communication and interpretation whereas administrative functions include a well-known categorization of functions of administration originally suggested by Henry Fayol; forecasting, planning, organizing, directing, coordinating and controlling. These are the typical functions of an executive who has no sufficient time to carry out and an "assistant to" tries to decrease his burden by participating in the most of these functions (Urwick\&Dale, 1960:29). We will give here the brief definitions of these functions of executive and parallel work descriptions of the "assistant to" made by the authors.

Concerning the leading functions suggested in this model, initiation is described as the attempts of an executive to his institution to bring "new" with his leadership mostly by arranging change when and where needed. Authors claim that the research and development activities for the future, initiation of new projects and ideas can be regarded primary initiation tools (1960:31) In parallel to this function of the executive, assistant to probably deals with such affairs as realizing researches, investigations in the relevant fields, iniating new ideas, iniating new projects or joining in the execution of the projects (1960:146).

Interpretation is suggested as a function that an executive must spend a substantial time to make clear to his subordinates the reasons for policies, in persuading the subordinates of the necessity of changes. As a related function, communication takes place as an inevitable part of leadership in authors' argument, enabling the executive to appreciate the thoughts and feelings of the subordinates. In the mean time, his thoughts and feelings are necessary to be known by the rest of the organization. As parallel to the combination of these functions, assistant to act in a liaison capacity between the organization and the executive. He interprets the opinions of the executive and communicate them to the organization, reversibly, communicate the ideas, recommendations and problems of the organization to the executive (1960: 227).

As an important component of the leading functions of an executive, representation includes the activities of an executive as the representative of his organization concerning the maintenance of the relations of organization with the 
environment in rough sense. It is not difficult to guess probable activities of an assistant to like interviewing, contacting, receiving inquiries from relevant external groups and persons in the context of public relation activities as the representative of the executive.

Regarding the "administrative" functions, authors use the classification originally suggested by Henry Fayol as mentioned above. As known, similar categorizations are used to define the functions of the administrator by the other writers as it is in Gulick's famous POSDCORB, then, these are widely accepted as the functions of a typical administrator. Even if they are formally delegated to other units, an executive as the head of the organization is assumed to have the primary responsibility for the carrying out of these activities properly.

As will be remembered they defined one of the reasons for the existence of a personal assistant is defined as doing jobs executive can not delegate to any other person than his closest aides. As parallel to the executive's responsibility of these functions, an assistant to would have functions relevant to them. In the authors' opinion, assistant to may not always directly parlicipate in the activities of the administrative units carrying out the specific functions sometimes they carry out controlling function to keep the executive informed of what happens.

We have made an overview on Urwick \& Dale's analysis of staff in the form of personal assistance named assistant to an administrator in any kind of organization. We will benefit from their model of assistant to and function classifications in the later parts of our study and will refer to their definitions.

\subsection{Adviser to a Political Executive}

Up to here the emphasis of our study has been on the analysis of staff as the origin of advice phenomenon and as an assistant staff to any kind of administrator, thus, we have touched on the rather generalizable features. Nevertheless, as we indicate before, such a position can be influenced by many determinants like the sides in the relationship, the type of organization, then it is reshaped and redefined in each case. At this point we will turn our analysis more to the concepts of advice and advisers. Especially, in the case that a political executive stands on the counter side, there remain many points that may not be foresighted by organization theorists. Additionally, adviser has been the commonly used term to identify a personal assistant to an executive of any kind in the contemporary practice rather than the terms like assistant to, personal assistant and else.

It may be expected here that definition of the term adviser would be given and further explanations on an adviser's functions would be made beyond the simple and general definitions. Nonetheless, the term adviser lacks both in political and administrative studies a well established meaning. This mainly stems from the wide variety of adviser's roles as compared with the other political and administrative officers whose status have been well defined by law or custom.

Because of the amorphous and ambiguous character of the term, the answer to the question who is to be included as an adviser changes according to the numerous factors ranging from the characteristics and the expectations of the individuals in the advising 
relationship to the political and bureaucratic cultures, legal and institutional frameworks, traditions of the different societies.

In addition to that, studies that examine the theme of advise and adviser in a systematic way are rare in number. Some of the present studies are autobiographical based on the personal experiences but most of them indirectly deals with the issue within the analysis of bureaucratic and political systems. ${ }^{2}$

Although it is difficult to derive overall generalizations, to review several "definitions" mostly reflect the practices in different countries might be useful for us to have an idea.

As one of the few authors work on the subject of advice and adviser, Herbert Goldhamer had tried to constitute an image of adviser by studying practices through history from ancient times to our age in his sophisticated and interesting book. In his words, an adviser to a political leader is,

"...a conscience giving moral instruction,

...a provider of judgment and wisdom, analytic and professional skills with the ability to apply these talents to politics,

...a sounding board for and critic of ruleris own ideas and plans,

...a friend who facilitates the leaderís inner dialogue..." (Goldhamer, 1978:7-27)

Yehezkel Dror, another author who studied fundamental issues involved in providing advisory support for top public executives presents advisers, firsly as mentors to rulers, providing them knowledge to overcome incompetences as wcll as the aides in educating roles through influencing rulersi way of thinking and teaching roles in the analysis oriented, technical issues (1987:196).

A similar conception of adviser is observed in the analysis of another author classifying advisers according to their "hats" they wcar in accordance to the roles expected from them (Dougherty, 1990:27-31). In this classification, advisers may take roles in six different types of roles as Expert, Trainer - Educator, Advocate, Collaborator, Fact finder, Process Specialist.

If we look at the descriptions of these roles briefly, An adviser in the Expert role, provides knowledge, special information or service upon request of the administration or to recommend solutions to previously defined problems. A Trainer-Educator adviser serves as similar to the Expert with a difference that helshe can be more creative, active and initiative to imply changes in decisions. An Advocate adviser attempt to persuade decision maker to do something he seems to desire. A Collaborator helps the decision maker in negotiating with he clients of the organization. Adviser in a Fact-finder role is defined as the simplest form of the roles that merely involves obtaining information, analyzing it, to find answers to "what" questions whereas a Process Specialist focuses more on the "how" questions concerning the process rather than the structure and the content of the issues.

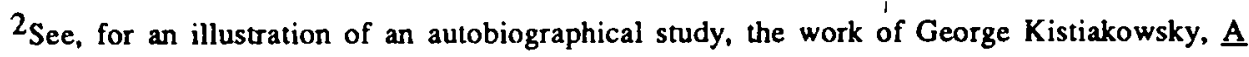
Scientist at the White House, Harward University Press, 1970. 
These descriptions of Dougherty is made considering any kind of organization and administrator who appeals to an adviser and is not specific to a political executive. It can be observed yet he uses similar expressions with the former definitions mentioned in a more systematic manner.

If we turn to definitions based on the practices in different countries, we can see interesting descriptions as Joan Mitchell does by making reference to the work of the advisers to the ministers in Britain (Mitchell, 1978: 87). In his expression, an adviser work,

"... as a seive, examining papers for politically sensitive or other important problems; as a deviller, chasing ministers' requests or instructions; as a thinker on medium and lon-term planning; as a policy contributor to departmental planning groups; as a party contact man, keeping touch especially with the party's own research department; as a pressure group contact man; and as a speech writer..."

As another example, examining the practice in United States, Page names the advisers as program managers who advise on the basis of expertise, as policy analysists bringing analytical skills to bear upon a range of policy problems and as staff cronies, those who are close to the client and who offer personal friendship and advice in addition to performing tasks such as opening letuers (Page, 1985:119).

According to another writer explaining the practice in American Presidency, the presidents may turn to advisers to satisfy'a number of needs concerning decision making (George, 1982:81). Firstly, it can be to provide information to satisfy cognitive needs prior to make decisions. Secondly, the chief executive may interact with advisers in order to obtain the emotional support needed to cope with the strains of making difficult decisions. Thirdly, since consulting with advisers give them the satisfaction of knowing their views were considered, it may be useful to the President for gaining their understanding and support for decisions he made. And finally, by taking advice from proper and influential persons, he may want to gain greater political legitimacy in the eyes of public for his policies and decisions. This can be taken as an illustration of the definition of adviser by the reasons of his existence.

As we observe, even though some common points exist in different discussions on the role of advisers, to make generalized definitions is still difficult since the range of determinants on their roles extends from the culture-specific ones to the expectations of the parts from the advising relationship. At the end of this part we will discuss on the "possible" roles and functions of advisers again but before that, we will examine some dynamics to find the answer to the question why political executives need special advisers.

\section{INCENTIVES FOR POLITICAL EXECUTIVES TO HAVE ADVISERS}

Even if it is difficult to answer the question exactly that why executives need to interact with advisers, since they have varicty of reasons ranging from individual reasons to the political incentives and to the specific necessities of their organization, it is necessary to touch on some of them. 
Before entering this discussion, we must state that the terms used interchangeably like political ruler, political executive, political leader refer to the elected heads of the governmental bodies that are influential in the policy process.

\subsection{Knowledge Necessities}

One of the common discourses of today is mostly expressed as "we live in the Information Age" and it is one of the themes occupying agenda of the today's society. Beyond to what extent the discourses on the information and its use reflect the reality or include illusive aspects, it is easily observed that the excessive amount of information lead to countless variety in the areas of expertise. It is difficult today to determine the limits of knowledge and skill necessities of the organizations.

It is not difficult to see that the origin of this situation is related to the present economic and political system. This relation is well explained in the Schumpeter's view of the capitalist system, arguing that capitalism is characterized by creative destruction. 3 It is creative because profit seekers are pushed to develop new products, to implement new technologies to cut costs, to establish new firms to enter market.On the other hand, it involves destruction since this process neccessitates the abandonment of outmoded technologies and products, the devaluation of hard-won skills, and the decline of firms that fallen behind these developments.

Given this view, one of the important effects is the subjection of technical skills and knowledge of the workforce to a continual process of replacement, where old skills are outmoded by technological change with the challenges for new skills as expressed in "skill replacement" theories of some sociologists (Penn and Scattergood, 1985: 611-30).

Finding the sources for information necessities is not always easy for an organization with limited skilled personnel. Reaching the speed of technological changes by continuous "skill replacement" is too costly and the employment of the high caliber personnel with all necessary skills and expertise is nearly impossible within the limitations of the resources.

Up to the human resources implications of knowledge gap under technological imperatives, organizations has been forced to make new structural adjustments to solve problems. Except the above mentioned costly measures, temporary employment of skilled personnel in accordance with the needs has become a common practice. As we discussed in the part about evolution of staff concept, this development reflects the ransformation in the employment of professionals whe possess. even "owns" their knowledge as their property that can not be bound to a career in a certain institution.by his feature, who challenge traditional roles in the organizations. As Caplow expresses "the modern professional is likely to be an expert and his skills may be usable in hundreds of different places..." (Caplow,1964:244).

${ }^{3}$ This concept is discussed in detail in Joseph Schumpeter, Capitalism. Socialism and Democracy, (London: Allen\&Unwin, 1952). 
Advisory positions are mostly used to employ the experts having skills and knowledge usable in hundreds of different places generally on temporary assignments or on the part time basis. Beyond this becomes a necessity implied by above mentioned factors, some defend the idea that this practice can be regarded as advantageous for today's organizations that suffer from financial restrictions by bringing the opportunity to reduce the number of permanent specialist staff (Peet,1988:13-17).

Even the temporary employment of "outside" experts in the advisory positions seems to become unnecessary at future since advice or consultancy has become a profession of its own. The most impressive illustration of this development is the management consultation firms whose job is "to sell advice" to the organizations that demand advice in a wide spectrum ranging from auditing to the personnel management from these firms that nearly take over the functions of top management (Belman,1990:185).

Our discussion up to here are related to general implications of knowledge gap due to the technological, economical imperatives, fast moving institutional changes. Political organizations or political executives can be assumed to have the similar motives to recruit expert advisers for informative contribution. On the other hand, there are different views on the use of expert advice by political executives.

As one of them, Peters and Barker, calls attention to the other side of the discourse on the necessity of experts in the "age of information." In their argument, the need for expert knowledge is just one aspect of the reality, the other side is the attempt of policy makers to claim that they received information and advice from experts thus the search for "authoritativeness" of the decisions in the eyes of the public opinion. (Peters and Barker, 1992:25)

Another different approach to the use of expert advice by politicians is that of Plowden. He thinks that reasons behind the bringing outsiders to official positions rather than consulting them occasionally when necessary might be different. One of these reasons can be to prevent academics and scientists who do not share common culture with governmental officials from criticizing governmental affairs freely by giving them official status that have binding features. This is seen as more eminent way of getting advice for politicians than receiving it occasionally from outside experts who are feared since they can manipulate information they would receive in the advising relationship on govemmental affairs having secrecy (Plowden, 1987:174).

\subsection{Political Factors}

Easton suggests a model of political system through which inputs coming from the environment in the form of demands and supports are transformed into outputs in the form of decisions and policies (1957: 28-44). Policy makers have been increasingly subjected to the influences and demands of the individuals, groups, governmental or nongovernmental organizations. "Government is a part of the daily life of the average citizen" as Peters indicates and increasing government intervention brings more interaction between them (1984:30). The public affected from the extended interventions has become more demanding in the play of politics. Policy makers have difficulties to cope with and to comprise these demands coming from different sources composed of 
interest groups, voluntary organizations, parties, sophisticated client groups and other organized public as well as citizens.

Varying in the degree of influence according to the political culture, prevalence of interest groups in the politics is a reality even if some criticisms rise against it with the argument that interest group politics causes the public authority parceled out negating democracy and results in weak, decentralized governments incapable of doing long range programs. (Lowi,1969).

Beyond the influcnce on the party politics and on legislature, intervention of the organized interests in the bureaucracy by political officials broadens the considerations affecting governmental decisions. The allocation of advisory posts to the representatives of the organized groups as the symbols of participation of interests in the decisions becomes a common practice enabling them to play a negotiating role between policy makers and these groups. It is described as the "formal" participation of a number of associations in the administrative and policy process by means of these "outsider" representatives as a symptom of the corporatist framework (Lehmbruch and Schmitter, 1981:39)

Besides the personal advisory posts, advisory structures in the form of councils or committees are also widespread in the various administrative systems to enable the participation of outsiders in policy process. In Britain, as an example, advisory committees composed of departmental officials and representatives of client groups work to achieve consensus through negotiation and consultation on policies and to submit an "agrecd policy" to ministers (Greenwood and Wilson, 1989: 33-34).

As similar to that, in Japan, advisory councils attached to national and local agencies include representatives of the major parties, business, labor, powerful interest groups, academia conduct inquiry or advice on important issues and policy questions (Hitoshi, 1990:39-45).

These examples can be augmented in the practice of many other countries. What is common is that they indicate the framework of contemporary politics. Consequently, policy makers may have opportunity to prove to the pressure groups that policies and decisions are constituted through agreements with them as an attempt to legitimize policies.

\subsection{The Political Exesutive and Bureaucracy}

"The political master finds himself in a position of a dilletante who stands opposite the expert facing the trained official within the managment of administration" (Weber in Gerth \&Mills, 1948:232)

Above statement of Webcr express the situation of the politician who may feel a feeling of powerlessness against the bureaucratic power. Rourke explains the source of the bureaucratic power as the expertise administrators bring to the policy process by the variety of skills necessary for making decisions on policy and carrying these decisions out. This is not exactly same with the expertise one gain through specialized knowledge in a profession. It is based on subpart specialization through that tasks are divided into smaller and smaller tasks, concentrated attention given to specific problems and exersized 
through the administrative advice and discretion that refers to the ability of an administrator to choose among alternatives (Rourke,1969, 39-61).

"Bureaucrats" says Putnam, "monopolizing as they do much of the available information about the shortcomings of existing policies as well as much of the technical expertise necessary to design practical alternatives, have gained a predominant influence over the evolution of the agenda for decision...." (1975:87)

Technocratic views, some way can be traced back to James Burnham's thesis in The Managerial Revolution (1942) attributes a great power to bureaucrats in the policy process that's source come from expert technical knowledge. Bureaucrats with their institutional experience and technical expertise are perceived as a treat by political leader because of the possibility that they can try to manipulate decisions of the executive on their own favor of choice. (Etzioni, 1985:57-58) The executives having doubt and fear of the bureaucrats try to counteract bureaucratic power, in order to control it and not "to become a prisoner of their own bureaucracy" in Riggs's terms, recruit outsiders who are symphatetic to their political choices to advisory posts with temporary basis (Riggs,1968:158).

Political and bureaucratic culture is influential in to what degree outsiders are favored or having priority and influentiality against the bureaucracy. Smith indicates the situation in US where one government's top officials are replaced by others supportive of the newly elected government, making reference to an advisory committee chairmanís words saying "...we have so many advisory committees because we are a free market private sector society. We don't belicve in bureaucrats running everything..." (Smith,1992:9).

On the other hand, in countries that have a strong administrative tradition, there can be criticisms against the extended use of outsiders, as in Britain, with the idea that it can lead to politicization of bureaucracy (Greenwood,1989:97-99).

As an additional important point, bureaucracy's weakness in "evaluation" of knowledge what a political executive is considered to need is another argument in explaining the reason of executives to have advisers. In this argument, even if the civil servants are perfect in expertise and belicved as eminent by the political executive, they are still far from giving proper advice to him who need more interpretive advice having both technical and political concerns. It is believed that the distinction between technical expertise and political argument is often broken down through the external consultants (Henkel,1991:127)

Mitchell indicates another weakness of bureaucrats in helping political executives caused by the reason they are civil servants who have little chance to have close personal involvement with political organizations making them far from being familiar with the pressures on the executive. In contrast, some of special advisers have been themselves pressure group members and better able to contact outside groups for getting support and contact quickly. Additionally, they often know well what sort of information his minister needs, partly from personal knowledge, partly from shared political responses enabling them to provide better proposals taking care of outside alliances (Mitchell,1978:89-92). 


\section{AN EVALUATION OF THE FUNDAMENTAL ISSUES and RESEARCH PERSPECTIVES}

In this part we will try to examine some fundamental issues concerning advisers to executives on the basis of the practices in different countries besides the theoretical approaches. Our aim is to facilitate the understanding of the concept of "adviser" that we analyzed within a theoretical frame in a more concretized manner. Although giving descriptive and definite answers that can be generalized to all practices is still difficult, the review of fundamental issues in the different practices of advisory systems can contribute to broaden our view on the issue.

It should also be recorded that examples on practices are mostly drawn from practices in Western European governments or in United States since present studies are available mostly in these countries.

\subsection{On the Selection And Status of Advisers}

One of the most difficult questions to be answered concerning advisers is how they are selected and what their status is. Their organizational status is defined in staff positions that are directly placed under the authority of the executive and they have no formal superior - subordinate relationship with the rest of the organization. It is observed that unofficial or semiofficial status is common as well as official status of staff occupying advisory positions. There are illustrations like Prime Minister's political advisers in Britain operating in the individual capacity without official status (Pyper, 1995:95), or some special assistants in the White House Office of US Presidents without any formal titles, without prescribed responsibilities and even sometimes without compensation (Sharkansky, 1982:81).

Simon and others indicates the difficulty to determine the features of personal staff of an administrator by just conceptual definition as staff officer without examining practical situation, since the preferences of the administrator is determinant (1985:224). It is really difficult to determine critcria in the selection for the positions personally serving to the executive. The executive normally has a great initiative in selecting his advisers, so very personal and subjective factors can be influential. Political affiliation, ideological consistency or personal intimacy can be regarded as the principal factors for a political executive in selecting personal staff.

The temporary status of advisers as well as the individuality in their service is a factor leading these positions to be far from prescriptions. A personal advisory position is difficult to be defined as a career position since it is not a profession of its own. Then, can we evaluate advisory positions as a special group of occupation? It also seems to be difficult since some necessary conditions to be an occupational community like having identity by their job, having community consciousness and internal control mechani sms can not be claimed for the position of advisers (Maanen and Barley, 1984:287-265).

Then, it can be argued that the relativity is dominant in terms of features concerning the professional and occupational backgrounds of advisers. Especially in the case of advisers to political executives, the features of administrative tradition can be an important factor as well as the specific needs and expectations. In some of the countries, we see a high rate of civil service orientation in terms of previous occupational 
backgrounds like it is in France where the administrative class with an experience based on a career through prescribed channels is a valuable source of knowledge for political executives (Pouydesseau, 1975:197-203).

Similarly, in German ministries, most of the personal staff functions are carried out by younger civil servants, even if there is no special political staffs (Derlien, 1995:79). On the other hand, in the practice of US, besides the general experience and specific expertise, political considerations including service to the party is assumed to be greatly weighted factors in choice of the President (Mann and Doig, 1965:88-89; Kessel, 1984:233).

As a result, we can say that features characterizing the status, selection, professional and occupational backgrounds of advisers to political executivesican change in each case. From the personal preferences of the executive and the specific needs to the characteristics of the administrative systems, there is a wide variety of factors that can be influential. Then we thought that we could not define what features advisers ought to have but we could reveal what features advisers have by inquiring some variables like legal status, education, age, occupational and professional background, interest in politics which would give us the opportunity to understand the descriptive characteristics of advisers.

\subsection{On What Advisers Do}

Giving an accurate answer to the question what advisers do is quite difficult since there is no clear establishments of their roles and functions in most of the practices of advisory systems. The lack of adequate litcrature dealing with what the adviser actually does as well as the nature of advisory positions explained before creates difficulty in defining the functions of advisers. Despite these difficulties, we thought that we could investigate the roles that advisers are mostly assumed to play and functions they mostly perform in the light of the discussions on staff and of the different practices of advisory systems. This might provide us to have a more or less adequate picture of what advisers do.

We had discussed the model of assistant to an executive developed by Urwick and Dale (1960) by comparing the practices in military, business and Presidential organizations in US. In their definition, assistant to was defined as the personal staff who worry about the things his chief-worry and who perform the duties the executive could not delegate to other persons except the close aides, as the general principles drawing boundaries of the assistant to's functions.

After giving this general frame, the authors had classified the functions in to the two categories, one is concerning Leading functions of the executive including Interpretation, Communication, Representation, Initiation and the other is conceming Administrative functions of the executive including all typical ones like forecasting, planning, organizing, directing, coordinating and controlling. The authors had assumed that these are the typical functions of an executive and an assistant to would contribute to all these functions as convenient to the principle his duty is to worry about the things worry his executive. 
This model can be accepted as general frame to examine the functioning of the personal assistant for any kind of executive. As a matter of fact, we observe advisers in different practices perform similar duties. As an example, representation is one of the important functions of advisers in contemporary practices. They can perform duties like maintaining communication with outside groups like other governmental organizations, political parties, pressure groups and negotiating with them to present policies and decisions with the aim of learning their reactions and to gain their support for the policies by engaging dialogs as the representative of the executive (Blackstone,1988: 71).

Administrative functions constitute a major part of the functions in most of the advisory practices. As an example, French ministerial cabinets that are the institutionalized advisory organs are known as the right hand of the minister in the administrative affairs, coordinating and resolving conflicts between different units of the ministry, interfering with the affairs of the department heads and middle managers (Rouban, 1995:49).

As in the case of Germany, some advisory staff to the minister serve in the research, planning and documentation functions that are originally realized by the related line units (Derlien, 1995:80). It is clear that the active participation of the advisers in the administrative activities is not rare besides their controlling activities on the administration.

In the writings on the advise and advisory systems, another mostly discussed issue is the role of advisers in the decisionmaking of the executives. This is natural since whatever the type of organization they lead, one of the primary functions of the administrators is regarded "decision making". Gulick, in his famous POSDCORB formula defines Directing that is one of the functions of the administrator as giving decisions continuously and transforming them to the orders (1937:13).

On the other hand, "an executive decision is only a moment in a process" as Follett observed and different actors in the environment of the executive play roles in the stages prior to the decision taken at the last stage. Therefore, advisers as one of the closest people around the executive are expected to have influence in the decisions. Type of decisions as well as the stage of the decision process they contribute is suggested as important factors affecting the degree of advisers' influentiality. (Topf, 1993:191-195).

As remembered, we mentioned that the advisers' functions can modify according to many factors and added that the type of executive they serve and mutual expectations from the advising relationship are the most important ones among them. In this respect, if the executive on the side of advisee is a political executive, adviser's role and area of function may exceed the limits the specific organization that executive lead. A political executive is a part of policy process and this means he has various responsibilities concerning the whole process that is qualified by the specific political system. If we take the parliamentary-cabinet regimes into account, a minister or prime minister would be a part of the legislature as well as of the executive as a primary figure having roles in the whole policy process. Then, an adviser mostly has duties concerning the functions of the executive related to the different parts of his responsibilities in the policy process. (Blackstone, 1979:71). 
Up to here we have tried to analyze the areas of function advisers are mostly assumed to contribute. In other words, we discussed the answer that could be given to the question "In what areas of function an adviser may contribute to the executive". To summarize, in parallel with the general principle that assumes an adviser perform duties concerning the functions of the executive, an adviser would contribute to the leading functions including initiation, interpretation, communication, representation and to the administrative functions by either participating in or controlling the activities of other units of the organization. Additionally, they are also assumed to have roles at the top level decisionmaking and activities concerning the roles of the political ruler having identity related to the other parts of the policy process like legislature other than being the head of executive organs. Then, these would be the variables in our research to inquire the main functions of the executive that an adviser is assumed to take roles.

On the other hand, to have a correct understanding of the adviser's functioning, finding the answer to the question "how an adviser contributes to the functions of the executive" is important as well as "what the areas of function advisers have role are". In other words, how does an adviser manage to be "eyes, ears and hands" of the executive in performing his duties?

To seek the answer of this question, we have developed some concepts categorizing the interrelated contributions of an adviser by resting on the information derived from the discussions on the various related subjects including the staff concept, staff assistants to executives, reasons behind the interaction of political executives with the advisers and so on. In this categorization, we assume that advisers help the executive in the various areas of function by informative, evaluative, monitoring, participative and innovative contributions. Mean while, these concepts would be the variables for our study to measure the advisers' effectivity as well as the way they contribute to their executive. We will try to explain these concepts one by one at the remainder of this part.

We had developed the concept of informative contribution by being inspired to a great extent by the perception of the staff as observed while we were examining the concept through different points of view in Organization Theory. The common point on the perception of staff's functions has been presented as providing information and knowledge mostly based on their areas of specialization especially in technically based tasks.

This kind of functions have been suggested in the form of specialized expert advice provided by the analysists, professionals involved in the technostructure of the organization in the Mintzberg's definition(1983:134) Gathering and analyzing necessary information, developing technical aspects of the works, realizing research activities and like that are the examples of the typical contributions of staff as the source of the information.

We had witnessed that there are some definitions perceiving the adviser as the person whose job is just to give purely objective technical support without any political, judgmental appraisal, like in the suggestion of Douhgherty as Fact-finder and Expert types in his classification of advisers (1990:28). We accept that it is one of the contributions of adviser to the executive in the various areas of functioning defined as informative contribution. 
We also accepted that evaluative contribution that can be regarded as the complimentary to the informative contribution is another major contribution of an adviser made. It is given great consideration by the authors who challenge the idea that an adviser can give pure technical objective advice without taking political sensitivities into account. Peters and Barker criticize that the kind of advice in the form of "raw facts" and add that "they may be almost useless unless they are placed into a framework relevant to government and its policy tasks..." (1993:4). A strict distinction is difficult and useless to make between the advice based on "facts" intended to enable a policy maker objectively to predict the likely outcome of a policy intervention and "opinions" that can be primarily for a political analysis whether that intervention should be undertaken.

Mitchell thinks in the same way by stressing that the existence of "special technical advisers" other than expert bureaucrats who can do the same job is because of the executives' need for aides who can judge the technical details and alternatives by taking it's social and political consequences into consideration (1978:89).

The possibility of objective advice in the form of pure technical information is challenged by other reasons like that a technical adviser can even sometimes must determine some priorities in suggestions since busy executives mostly have no time to read, analyze all data presented to them. They are inevitably in need of the evaluated knowledge convenient to their objectives. In addition to that, politicians mostly tend to choose advisers whose political views are similar to their own, then, technical and political dimensions of advice become unseparable (Primack and Hippel,1974:38-40).

In fact, the idea that professional adviser gives pure technical advice without any evaluation that is mostly traced back to the staff function defined in Classical Theory had been challenged even by Urwick known as involved in this school who says that pure advice and synthetic investigations on particular issues without analysis and correlation increases the burden of the executive (Urwick; 1937:61).

While we were discussing on the incentives of political executives to have special advisers we had indicated that the position of them against bureaucracy is one of the most important factors which make the executives feel the need for special advisers. This encouraged us to consider that advisers also contribute to the functions of their executive by monitoring the administration.

Political executives are mostly assumed to be afraid of bureaucrats who may attempt to manipulate their decisions and they are forced to control the proposals submitted and the activities realized by the burcaucrats. Appealing to personal advisers is preferred by the political executives as one of the most eminent ways in controlling bureaucracy.

We observe the monitoring role of 'advisers on bureaucracy in the practices of different countries. To illustrate, controlling administration in the name of minister is regarded among the most ímportant functions of French Cabinets that realize advisory services to minister. In this respect, they are regarded as serving to strengthten the position of executive in the organization or to control organization in the name of leader and particular objectives.(Pouydesseau, 1975:205). 
As another example, beyond the monitoring organization and commenting on the recommendations coming from civil service, The Prime Minister's Policy Unit, also known as the Number 10 Policy Unit in Britain is considered as a measure against the disadvantages of civil service recommendations that are claimed to lack the commitment to implement radical policies with a passive and too objective approach in their advice. It works like Prime Minister's office and one of its major functions is to brief on the departmental policies, evaluate and comment departments' work and providing communication and coordination among the variety of functions, but at the end, it is considered as a tool increasing centralized power of Prime Minister (Willetts, 1987:451$455)^{4}$.

In some way, monitoring contribution of advisers can be regarded as parallel to their evaluative contribution in the sense that 'they present comments on the tasks realized by the administration in the light of political priorities. It can also be regarded a part of their functions as parallel to the administrative functions of the executive as we have discussed in the Urwick and Dale's classification of functions. If remembered, they indicate that advisers contribute to administrative functions of the executive either participating in or controlling the activities of the administration (1960:29).

Advisers are usually assumed to have no formal relationship with the organization led by the executive they serve and they seem to have no direct relation with the activities of the administration. However it is not rare in the practice that advisers directly participate in the activities of the organizational units on the request of the executives and sometimes in the name of them (Derlien, 1995:79). This was also stressed in the conception of Urwick and Dale giving examples from the research they conducted on the functions of assistant to serving to the executives in various sectors (1960:143-149). Thus, it would not be inconvenient to say that advisers contribute to their executives by participating in the activities of administration.

We examined another concept on the contribution of adviser that is rather used to qualify the effectivity and autonomy of them. It is the innovativeness or initiativity of advisers. Dictionary definition of the word initiative is given as "the first movement or act which starts something happening" while the word innovation is defined as "the introduction of something new"5.

These two terms are used by some in the literature on administration. March and Simon explain Initiation as a concept qualifying the attempt to change in "going concerns" and also explain the concept of Innovation qualifying the process referring to "creative thinking", " invention" and the like (1958:173-177).

These two concepts are usually perceived in a coalesced meaning in the literature on the advisory systems referring to enterpreneurship in agenda-selting. Dror states that limited innovativeness and enterpreneurship is one of the dilemmas for advisers leaving them in the situation they respond to the agenda imposed on them by the executive and

${ }^{4}$ Departments, in the British administrative system, includes ministerial departments (ministries), non-ministerial departments and semi-auonomous agecies. See, for details, J. GREENWOOD AND D. WILSON, Public Administration in Britain today. London: Unwin Hyman Inc., 1989)., shp. 2.

${ }^{5}$ Longman Dictionary of English, 1987, pp. 316-317. 
by external pressures rather than in engaging initiative in putting the agenda issues (1987:198).

The situation in the practice mostly justify this thesis. For the case in Britain, as an example, Pyper indicates that special political advisers in British system, even at the height of their influence, rarely play decisive role in the creation of policies and are rather 'reactive' in the sense that they operate in spheres with long-established policy links (1995:95-96). Suleiman describes the situation in France in his statement that the role of the cabinet is rather to strengthen the role of the minister than to contribute to determining the agenda of the policies (1974:141-145).

We have tried to get a picture of what advisers do in parallel to the functions of their executives as well as how they do in terms of the main ways they contribute to these functions. Especially, we have tried to bring explanations on the way of their contributions. It must be emphasized that the functions and contributions of advisers we attempted to classify are mostly interrelated in practice, it is usually difficult to say that an adviser just serves as informative staff or just monitor the administration. As we explain above these can be regarded as the classifications on the spectrum of the activities that are complementary for each other. In other words, they are the different "hats" advisers wear in accordance with the expectations of the executive, conditional necessities and the characteristic of the specific advising relationship between them and the executives.

Consequently, we can say that we would take the informative, evaluative, monitoring, participative and innovative contributions as the variables in investigating how they realize their support to executive.

After the discussions and different viewpoints reviewed throughout the study up to here, we could hopefully create more or less adequate picture of an adviser to a political executive in terms of organizational status and functions. If we seek to develop our own description on who an adviser is in a few summarizing sentence, we can say that;

"An adviser is a personal staff who is directly bounded to the executive in status, and as a general frame of the duties, is an assistant performing duties that are parallel to the executive's functions and expectations. While performing these duties in parallel to the functions and responsibilities of the executive, an adviser assists the executive by informing him on the technically based affairs on the basis of his expertise, by evaluating this technical information under the political priorities of the executive, by monitoring the activities of organization led by the executive in terms of consistency with these political priorities as well as by participating in these activities as an informal representative of the executive or for the sake of his own expertise."

\subsection{On How Advisers Work}

Work pattern of the advisory systems has often been subjected to discussions since it is not just regarded as a totality of the formal arrangements. The nature of the advisers' work is assumed to affect the advisory relation. Controversial arguments are mostly focused on the discussion of the question whether advice should be formalized or left informal (Seymour Ure, 1987:175-184). Formality is suggested to involve the explicit, 
formal definition of tasks, procedures and responsibilities of advisers as well as their relationships with each others and with the executive on a formal, regular pattern. Informality refers to a more spontaneous mechanism through which personal relations dominate, separation of functions and tasks is rare, adviser and advisee in a more implicit, secret position.

In fact, as it is difficult to say that the work of an advisory system is qualified by just informality or formality. It is more proper to say that formality and informality can exits in a system by different degrees changing according to the factors like expectations and attitudes of the sides in the advising relationship.

The most advocated aspect of formality is that it makes functions of advisers and relations can be kept clear and definite. Formal mechanisms are assumed to be useful to identify where ideas come from and what the apparent sources of influence over policy are. It is assumed that it facilitates the accountability of advisers in the sense that their activities are to some extend openly defined and acknowledged (Seymour Ure,1987:175176).

It is also assumed that formality enables the advisers more effective since it has continuity through regular meetings. Written reports as the part of the formality increases serious considerations and detailed analysis of the problems.

Some forms of institutionalized advise are illustrated for the extreme formality as it is in some advisory bodies like Central Policy Review Staff in Britain, Chancellor's Office in Germany or Council of Economic Advisers in US. Prescribed roles and functions of the members, regularity of work, recognized procedures can be counted some of the common features of them.

This kind of institutionalized advice is assumed to be favored especially in the systems with a strong administrative tradition where the advice of administration is given great emphasis and is not desired to be subordinated to the political advice. Institutionalized bodies of advice which are mostly composed of civil servants as well as outside advisers allow the political executives to realize this combination in receiving advice. In their pattern of work, it is observed that a mechanism of collective advice composing of the bureaucrats as well as the other advisers to the executive constitutes a dimension of formality in effect. It is also favored by the reason that the advice on a collective basis is more satisfactory for the executive by enabling him to evaluate different perspectives on a problem (Weller, 1987:150). Meanwhile, criticisms rise against the collective mechanism since it damages the individuality and intimacy in the advice relationship as well as secrecy (Mitchell,1978:91).

In fact, formalized advice is criticized concerning various aspects other than the matter of collectivity. In these contrasting views, it is argued that, formality eliminates spontaneity that implies open-mindedness and fresh ideas, limits the scope of information offered. Gormley indicates the appearance of fairness, accountability and clarity is provided by formality at the cost of restrictiveness (Gormley, 1989: 57).

Moreover, it is defended that personal assistance is hard to take pre-defined rules, functions and needs adaptability and flexibility because of the shifting roles in personal 
advising relations. Formality is considered as having destructing effect on secretiveness, intimacy, the frequency of contact in advising relations (Goldhamer, 1978:89).

It is a mostly shared belief that personal advisers are mostly expected to work on an informal pattern, at least it is hard to prevent informality even if formality seems to exist in principle. It is emphasized by Meltsner that rulers mostly prefer direct access to their personal staff through informal meetings and he claims that rulers do not have to listen to the advice of a particular advisory structure, in fact there is no way to box the ruler in (1990:128).

Level of communication of the adviser in the organization including both the executive and other top level administrators is also important in determining the direction of their work. In terms of intraorganizational communication, it might be a common belief that advisers have just contact with the executive and they do not directly deal with the other administrative units since they are primarily personal assistants. But as observed in French Cabinet Directors whose functions contains controlling ministry organization, or other cases they act communication channels between line subordinates and the chief executive, in the cases they are in charge of agency supervision ,as it is in US, directing career subordinates in the paths of righteousness with policies, their communication with other administrators or officials in the organization can exist changing in intensity (Mann\&Doig;1965:88, Pouydesseau, 1975:205).

In the light of these discussions, frequency and way of contact, the degree of formality and informality, collectivity in advising would be primary variables to evaluate work pattern of advisers in our study.

\subsection{On the Difficulties of Being Adviser}

Throughout the examination of the issue of advisers in various aspects we have always emphasized the difficulty in describing advisers' functions, roles, status exactly with several exceptions, since the individuality in the personal advising relationship make it open to the flexibility in terms of functions, roles and subjective factors can be very influential in determining the borders of the advising relationship. We can add here that this flexible, amorphous and ambiguous feature of advisory positions is the source of trouble for the advisers, too. Morcover, their status in the organization that is out of the formal structure except their dependence to the executive brings them to a disadvantageous position in many cases.

In short, advisers face some conflicts and difficulties caused by the special characteristic of their position. First of all, they are in the position of the "outsiders". There are disadvantages for such an outsider role concerning their relationship both with their executive and with the organization their executive lead. Secondly, they may confront dilemmas inherent to their function including role conflicts and difficulties that any typical staff official may suffer from in most cases.

It is obvious that to consider all dimensions of the problems advisers could face is not possible within the limitations of this study. Therefore we will limit the issue in some main areas of conflict. In the context of this limitation, difficulties confronted to the advisers in their relationships with the executive and with the administrative body led 
by the executive as well as the dilemmas caused by the nature of their job would be analyzed in our research in detail as the main sources of problem.

\section{A REVIEW OF PRACTICE IN TURKEY}

Concerning the practice in our administrative system, there is limited information on the issue of advisers and on the working of personal advising to political executives. In fact, the lack of information is one of the primary motives behind the intention to this study as we explained before. But it might be useful to touch upon some important points concerning our administrative system and review some features of practices on advisory cadres in the central administration before presenting the findings of our research.

Turkish administrative system has many features inherited from the last era of Ottoman Empire. Attempts to modemize bureaucracy that had started at the 19th Century continued to be effective in the Republican era with numerous social and political consequences. These endeavors for the modemization that was focused on the military and bureaucratic system in empire period had been tried to introduced to the social structure by Republican People Party (RPP) under the leadership of Atat, rk. Bureaucracy that was subject to modernization in empire period had become an instrument in the transformation of the society by imposing new value system in the new era. During that time, bureaucracy had been so identified with the RPP that many political party functions given to the civil bureaucracy as can be seen in some practices like provincial govemors being appointed as the chairman of the local party organizations (Heper, 1985:70).

With the beginning of multi-party era, this organic relationship between political and bureaucratic power had come to an end and a continuing clash between bureaucratic intelligentsia who are mostly originated from RPP and the new political cadres emerged. As the result, politicization of administration has become an important issue in the agenda of political and administrative system. The most important effect of politicization of administration has been reflected in the partisan and political attitudes in the appointments of high level civil servants that are mobilized with each new government coming to power (Ardanıç and Ergun,1980:1)

As observed in the result of a questionnaire conducted in 1968 among some academicians and politicians to learn their attitudes toward the appointments on the basis of political and partisan choice these developments had been subject to the various discussions and criticisms. (Tutum, 1968:168-177). What is often indicated in these discussions was that there is a nced for a mechanism that would enable political cadres to provide consistency between their political priorities and the working of the administrative machinery without destructing its neutrality. There were some proposals to realize it and establishing cadres of special advisers in the ministries was one of them. Some points mostly emphasized by these views proposing advisory positions were that these cadres would not interfere with the matters that is in the scope of the related administrative units' functions. Advisers would help the ministers in matters like making and implementing decisions as they would be convenient to the governmentis program, investigating daily affairs and informing the minister on them, evaluating technical reports. (Tutum,1976:22). 
The appointments of advisers that were proposed as a measure against some problems mentioned above are observed as a common contemporary practice especially in the central governmental organization. Advisory cadres under the common name Müssavir is one category in the current practices of personal advising to ministers. These cadres are legally covered as Exceptional Cadres in the Public Personnel Law with No. 657 (article 59). Additionally the Law on the Establishment and Duties of Ministries (Code with No.3046, art.27) and the Law on the Organization of Prime Ministry (Code with No.3056, art.21 and art.23) enables the ministers and Prime Minister to appoint Müssavirs who would serve in the issues having priority and importance in the ministerial affairs and leave their number to be determined by each ministry's own organic law.

Beyond the general legal status of them, we have no source to provide qualitative or quantitative information on the special advisers. Nevertheless views on them have been mostly in the direction that these cadres of advisory positions are mostly used by governments to take away high level administrators from their positions who could not be dismissed because of the legal security (Mcriç,1974:75) ${ }^{6}$.

In fact, it is related to the common problem in using staff services including research and planning units and legal advisory units that are seen as the exile for the unwanted officials or as reward for provincial administrators who are willing to transfer to central units (Saylan, 1969: 79-81; Eray:1975:105-134).

Moreover, some reports written on Turkish Public Administration also emphasize the problems in the practice of staff units. As one of the earlicst, Neumark had indicated Research Councils (Tetkik Kurullari) do not work as they should in his report (1949:55). Later, famous MEHTAP Report also emphasized the problems in the work of these councils like the lack of separation of their functions from line units, excessive and indefinite load of duties resulting in ineffectiveness (1963:127). KAYA, as the lastly written report, mentions same problems (1990:34). So all these criticisms prove that the misuse and ineffectivity in the use of staff units has become one of the chronicle problems of Turkish Public Administration.

As in the case of the other staff units, the partisan practices are also considered as the problem of the cadres of Müsavirlik. (Tutum,1990:38). On the other hand, we observe that the extended use of advisers either in the cadres of Müşavir or through the Special Advisers is a common practice of recent years.

What can be the reason behind this paradoxical situation concerning the practice of personal advisers in the central administration? In our opinion, to review some contemporary developments with the tendencies prevailing in the practices of recent governments concerning the administrative system would be useful to find answer to this question.

After the 1980s, we have witnessed a tendency toward pragmatism in the way of administration in Turkey as well as in some other countries that is mostly expressed in

6 Public Personnel Law with no. 657 limitates the appointment of officials to other positions by stating the cadre degree of the position an official would be appointed mst be equal to that of the position occupied (Art. 76). 
terms like enterpreneurship culture and managerialism that are rather consistent with the values of management style in private sector. In parallel to these developments, some values like efficiency, competition, risk taking, flexibility in changing conditions, personal vision have been tried to be adopted as the principles of new culture of administration.

It was clear that the new understanding of the administration would lead to attempts to structural adjustments on the existing system. As a matter of fact, we observe some practices illustrating these adjustments with important consequences on the administrative mechanism. The creation of "alternative bureaucracies" that are organized as autonomous or semiautonomous institutions mostly attached to the prime ministry, the increase in the number of ministries of state and the transfer of some institutions as attached or related organizations to these ministries, the development of the vast system of funds established mostly for central administrative organs as a measure against the budgetary control of the Parliament are the most impressive practices that reflect attempts in the direction of the structural adjustments (Güler, 1996:60-63).

These attempts to eliminate controlling mechanisms and the adjustments on the administrative system can be regarded as measures to facilitate the process of centralization and individualization of the political power. Feroz Ahmad, who study the recent history of Turkey, comments on these developments and indicates that these are the symptoms of patronage in both political and administrative arena that is most skillfully exploited in the period started with Turgut Özal in Turkish political history (1993:190-91).

There are some other practices that reflect the endeavors of political executives to individualize power against the bureaucracy. The appointments of the "princes" to the key executive positions generally on the preferences of top political executives is one of them ${ }^{7}$. The extended use of advisers especially in central administration can be regarded as another example of the tendency toward the creation of more centralized and individualized power that attempts to externalize the existing bureaucracy, being subjected to criticisms $^{8}$.

${ }^{7}$ The executives appointed to the key positions in the public bureaucracy in the period of governments coming to power in the 1980s, especially in that of Turgut Ozal, have used to be called "princes" in public opinion. Even if there is no sociological definition of "princes", they have often been subject to some of the studies examining recent developments in the social structure of Turkey. As one of them, Hayri Kozanoglu, in his book Yuppieler. Prensler ve Bizim Kuşak (1993) describes princes as the public version of the "yuppie" generation that refers to the abbreviated name outlining the profile of the modern businessmen as "Young. Urban, Professional". According to the author's description made by an ironic expression, the most common characteristics of "princes" are their CV's including education is USA and experience of work in international financial institutions, axaggregated qualifications of skill attributed to them as well as their close relationships with the family of Ozal. (1993: 191-206).

8 Besides the academical studies, the criticisms for this practices have often been confronted in media by the related news as well as by the articles written by the different authors, mostly indicating the corruption in the use of advisory positions For illustration, see Mümtaz Soysal "Tehlikeli Eğilimler" Hürriyet, 28.12.1994, pp 11. and New, "Bakanlık Danışman Dolu", Sabah, 15.09.1994, pp 7. 
In fact, the use of special advisers as against or as substitute to bureaucrats is not specific to our country. As remembered, the insufficiency of bureaucrats in providing the "evaluated" advice including political considerations as well as technical aspects has been regarded as an important incentive for the political executives to interact with special advisers. Especially politicians who aim to realize radical policies are assumed to tend to work with special advisers as we observe in some of the practices. As an example, in the writings on the administrative practices in Britain it is often expressed that the tendency toward the use of special advisers has increased in the period of Margaret Thatcher who is a well known politician representing a transformation in British politics (Kingdom, 1992:374).

If we turn to the problem in our country, in the light of above discussions we can say that the practice of personal advisory services in our administrative system displays a paradoxical situation. On the one side, the ineffectivity and corruption as the common cronical problem in the use of staff units in Turkish administrative tradition is also observed in the cadres of Müsavir that are subjected to politicized and partisan attitudes. On the other side, the extended use of advisers either in the cadres of Müsavir or in the position of Special Adviser as the result of the recent developments has become an issue open to various discussions and criticisms.

These contradictory practices lead us to think on the vagueness of the issue with many questions in mind. Who are the advisers in the practice of Turkish public administration? What do they do? How do they work? Are they really ineffective in the functioning as commonly claimed or can it be a prejudiced idea caused by the impression inherited from the general view on the misuse of staff services in Turkish public administration? Many new ones can be added to this list of questions that motivated us to realize this study. In the remaining parts of the study that are not included in this paper, we have tried to find the answers of these questions.

\section{CONCLUDING REMARKS}

In this paper, we have presented the conceptual framework of a study that aims to have a panoramic view of the personal advisers to top political executives in the Turkish public administration in the coniext of their descriptive features, functions, work pattern and some conflicts they are assumed to experience in performing their functions. Primary consideration that encouraged us to realize this study was the actuality of the issue in parallel to the extended use of special advisers by top executives around world. This has also been observed as a contemporary practice especially in the practices of governmental organizations in Turkey. The increase and proliferation of the advisory positions in governmental organizations has become a recent issue in the agenda of discussions and criticisms on the problems of administrative system. In addition to that, there was another point that is related to the issue caused by the criticism directed to staff as one of the problem areas in Turkish public administration.

On the other hand, the complexity of the phenomenon of advise as well as the absence of well-established and agreed meaning of the terms adviser and advice has created some difficulties in dealing with the issue. The primary reason for that is the ambiguity of these terms that may have different meanings in the framework of different cultural, political and administrative systems. 
Despite these difficulties we tried to clarify related concepts. First, we confined the issue by accepting advise as a form of relationship qualified by two main elements; the context of the advising relationship realized and the sides in the advising relationship. We regarded organization as the context of the advising relationship, political executives as the side receiving advice from the personal advisers who constituted the other side in the relationship.

From this point of view regarding adviser as an organizational phenomenon we started our analysis by examining staff concept in organization theory and staff in the form of personal assistance to the top executives as specific to our issue. We used some definitions and descriptions on the functions of personal staff to executives as a basis'for the conception on advisers' functions.

As the next step, we have tried to enrich our view of adviser by surveying the practice of advisership to political exccutives around the world. By the review of the issue within the fundamental aspects in practice, we have attempted to develop a more or less adequate picture on who an adviser is and what an adviser does. As a general principle in examining functions we accepted that an adviser as a personal assistant performs duties concerning all areas of function that his executive is responsible. In parallel to this, we adopted the view on the classification of the duties of a personal staff to executive concerning his leading and administrative functions as we analyzed in detail within the study. Additionally, we also accepted decision making and the responsibilities of the political executives concerning their role in the policy process as another important area of function which appeals to the contribution of their advisers.

In developing this frame, we have assumed that having an accurate understanding of advisers' functioning is possible through analyzing how advisers contribute to the functions of their executives as well as by defining what are the roles of advisers in these areas of function. In other words, we tried to describe how advisers manage to be "eyes, ears and hands" of the exccutives in performing their duties as "the extension of their personality" which is the feature mostly attributed to them. In doing this, we tried to bring explanations on the method of their contribution that we classified as informative, evaluative, monitoring and participative contributions which we assumed as the main roles advisers play interchangeably in accordance with the expectations of the executive, with the conditional necessities and with the specific characteristics of advising relationship between them and the executives..

In the light of the detailed analysis of these concepts on advisers' functions within the study, we presented the portrait of the adviser to a political executive as a personal aide performing duties parallel to the functions and responsibilities of the executive through the assistance he provides by informing executive on the technical affairs on the basis of his expertise, by evaluating this technical information under the political priorities of the executive, by monitoring the activities of organization led by the executive in terms of consistency with these political priorities as well as by participating in these activities as an informal representative of the executive or for the sake of his own expertise. 
After completing the analysis of adviser in terms of status and functions through surveying the literature on organization theory and on contemporary practices of advisory systems, we also searched some additional subjects that are relevant to the issue. One of them was the work pattern of advisers that is regarded as an important feature characterizing advising relationship. Some problems and conflicts that are often assumed to face advisers in performing their duties effectively was the other subject we investigated as an important relevant issue.

By the help of the perspectives we adopted, we constructed our research with the aim to make a descriptive analysis of the practice of personal advising to political executives in Turkish administrative system. In developing our assumptions we have been inspired by the general view of the staff services in our practice and recent tendencies affecting Turkish administrative system as well as by our survey on the literature including staff concept in organization theory and the various practices of advisory systems. Details on the methodology of the research and presentation of its findings have not been included in this paper. What we wanted to do here was to elaborate the conceptual bases of this research on which the emphasis of our study was placed.

\section{REFERENCES}

AHMAD, Feroz (1993). The Making of Modern Turkey. London: Routledge.

ARDANIÇ, Bülent, Turgay Ergun (1980). "Siyasal Nitelikli Yüksek Yönetici Atamalan" Amme Idaresi Dergisi. 13:2, pp.3-18.

BELMAN; Geoffrey (1990). The Consultants Calling: Bringing who you are to what you do. San Francisco: Jossey Bass.

BLACKSTONE, Tessa (1988). "Ministers, Advisers and Civil Servants" in John Morgan (ed.). Politics and Consensus in Modern Britain. London: The Macmillan Press.

CAPLOW, Theodore (1964). Principles of Orgaization. New York: Harcourt, Brace and world.

DALTON, Melville (1959). Men Who Manage. New York: John Wiley.

DERLIEN, Hans (1995). "Public Administration in Germany: Political and Societal Relations" in John Pierre (ed.). Bureaucracy in the Modern State: An Introduction to Comparative Public Administration. England: Edward Elgar.

DOUGHERTY, Michael (1990). Consultation: Practice and Perspectives. California: Brooks and Cole Publishing Company.

DROR, Yehezkel. "Conclusion" in William Plowden. Advising the Rulers. Oxford: Basic Blackwell, 1987. 
EASTON, David (1957) "The Flow Characteristics of Policymaking" in Fremont Lyden, George Shipman and Morton Kroll (ed.). Policies, Decisions and Organization. New York: Meredith Corporation,1969.

ERAY, Erses (1975). "Türk Kamu Yönetiminin Ozek Kesiminde Çalı̧an Hukuk Danışmanlarının Sorunları" Amme ıdaresi Dergisi. 8:1, pp.105-134.

ETZIONI, Eva (1985). Bureaucracy and Democracy: A Political Dilemma. London: Routledge and Kegan Paul.

FAYOL, Henry. "The Administative Theory in the State" in L.GULICK and L. URWICK. Papers on the Science of Administration. New York: Institute of Public Administration, 1937. pp.101-114.

GALBRAITH, Jay (1973). Designing Complex Organizations. California: Addison Wesley.

GEORGE, Alexander (1982). Presidential Decisionmaking in Foreign Policy: The Effective use of Information and Advice. Colorado: Westview Press.

GERTH, H.H. and Wright Mills (1948). From Max Weber: Essays in Sociology. Oxford University Press.

GOLDHAMER, Herbert (1978). The Adviser. New York: Elsevier.

GORMLEY, W (1989). Taming the Bureaucracy. Princeton University Press.

GREENWOOD, John and David Wilson (1989). Public Administration in Britain Today. London: Unwin Hyman Inc., 1989.

GULICK, Luther. "Notes on the Theory of Organization" L.GULICK and L. URWICK. Papers on the Science of Administration. New York: Institute of Public Administration, 1937.

GtLER, Birgül Ayman (1996). Yeni Sağ ve Devletin Değişimi: Yapısal Uyarlama Politikaları. Ankara: TODAıE.

HENKEL, Mary (1991). "The New Evaluative State" Public Administration. Vol. 69., Spring. pp.121-136.

HEPER, Metin (1985). The State Tradition in Turkey. The Eothen Press.

HITOSHI, Abe., Muneyuki Shindo and Sadafumi Kawato (1990) The Government and Politics of Japan. University of Tokyo Press.

KATZ, Daniel and Robert Kahn (1966). The Social Pschology of Organizations. New York: John Wiley and Sons. 
KESSEL, John (1984). "The Structures of the Reagan White House" American Journal of Political Science. 28:2, pp.231-259.

KINGDOM, John (1992). Government and Politics in Britain. Cambridge: Polity Press.

KOZANOĞLU, Hayri (1993). Yuppieler, Prensler ve Bizim Kuşak. Istanbul: Iletişim Yayınlan.

LEHMBRUCH, Garry and P.C. Schmitter (1981). Patterns of Corporatist Policy Making. London: Sage.

LONGENECKER, Justine (1969). Principles of Management and Organization Behaviour. Columbus: Charles E. Merrill.

LOWI, Theodore (1969). The End of Liberalism: Ideology, Policy and the Crisis of Public Authority. New York:W.W. Norton Company.

MAANEN, J. van and S.R. Barley (1984). "Occupational Communities: Culture and Control in Organizations" in B.M. Staw and L.L. Cummings (eds.) Research in Organizational Behaviour. 6:287 -365.

MANN, Dean and Jameson Doig (1965). The Assistant Secretaries. Brookings.

MARCH, James and Herbert Simon (1958). Organizations. New york: John Wiley and Sons.

MELTSNER, Arnold (1990), Rules for Rulers. Temple University Press.

MERIÇ, Osman (1974), "Siyasal Iktidar ve Yüksek Yơneticiler Sorunu" A mme Idaresi Dergisi. 7:3. pp.73-78.

METCALF, Henry and $O$. Urwick (eds.) Dynamic Administration: The Collected Papers of Mary Parker Follett. New York: Harper and Brothers Publishers., 1964.

MINTZBERG, Henry (1983). Power In and Around Organizations. PrenticeHall, Inc. Englewood Cliffs.

MITCHELl, Joan (1978). "Special Advisers: A Personal View." Public Administration Review. .56:1., pp.87-98.

MOONEY, James (1947). The principles of Organization. New York: Harper and Brothers Publishers.

NEUMARK, F. (1949). Devlet Daire ve Müesseselerinde Rasyonel Çalışma Usulleri Hakkında Rapor. Ankara.

PAGE, Edward (1985). Political Authority and Bureaucratic Power: A Comparative Analysis. Sussex: Wheatsheaf Books. 
PEET, J. (1988). "The New Witch Doctors" The Economist. Vol.13.

PENN; Roger and Hilda Scattergood (1985). "De-skilling or Enskilling?: An Empirical Investigation of Recent Theories of the Labor Process" British Journal of Sociology. 36:13. pp.611-30.

PETERS, Brian (1984). The Politics of Bureaucracy. New York: Longman.

PETERS, Guy and Anthony Barker (1992). The Politics of Expert Advice in Western Europe: Creating, Using and Manipulating Scientific Knowledge for Public Policy. Edinburg: Edinburg University Press.

(1993). Advising West European Governments: Inquiries, Expertise and Public Policy. Edinburgh: Edinburgh University Press.

PLANT, Jeremy (1983). "Line and Staff" in Thomas Lynch (ed.) Organization Theory and Management. New York: Marcel and Dekker.

PLOWDEN, William (1987). Advising the Rulers. Oxford: Basic Blackwell Ltd.)

POUYDESSEAU, Jeanne Siweck (1975). "French Ministerial Staffs" in Mattei Dogan (ed.). The Mandarins of Western Europe: The Political Role of Top Civil Servants. New York: John Wiley and Sons.pp.196-209.

PRIMACK, Joel and Frank von Hippel (1974). Advice and Dissent. New York: Basic Books.

PUTNAM, Robert (1975). "The Political Attitudes of Senior Civil Servants in Britain, Germany and Italy" in Mattei Dogan (ed.). The Mandarins of Western Europe: The Political Role of Top Civil Servants. New York: John Wiley and Sons.PYPER, Robert (1995). The British Civil Service. London: Prentice Hall.

RIGGS, Fred (1968). "Bureaucrats and Political Development. A Paradoxical View" in Joseph L. Palombara (ed.), Bureaucracy and Political Development. Princeton: Princeton University Press.

ROLF, Rogers and Robert Mc Intire (1983). Organization and Management Theory. New York:John Wiley.

ROUBAN, Luc (1995). "Public administration at the crossroads: the end of the French specificity" in John Pierre (ed.). Bureaucracy in the Modern State: An Introduction to Comparative Public Administration. England: Edward Elgar.

ROURKE, Francis (1969). Bureaucracy, Politics and Public Policy. Boston: Little Brown and Company. 
SCHUMPETER, Joseph (1952). Capitalism, Socialism and Democracy. London: Allen and Unwin.

SELF, Peter (1977). Administrative Theories and Politics. London: Georrge Allen and Unwin.

SEYMOUR URE, Colin (1987). "Institutionalization and Informality in Advisory Systems" in William Plowden, Advising the Rulers. Oxford: Basic Blackwell.

SharkanSKY, Ira (1982). Public Administration: Agencies, Policies and Politics. San Fransisco: W.H. Freeman.

SIMON, Herbert, Donald Smithburg, Victor Thompson (1985). Kamu Yönetimi. Çev. Cemal Mıhçığlu. Ankara Iniversitesi Siyasal Bilgiler Fakültesi Yayınları.

SIMON, Herbert (1957). Administrative Behaviour: A Study of DecisionMaking Processes in Administrative Organization. New york. The Macmillan Company,

SMITH, BRUCE (1992). The Advisers: Scientists in the Policy Process. Washington, D.C: The Brookings Institution.

SUleIMAN, Ezra (1974). Politics, Power and Bureaucracy in France. Princeton Universiry Press.

ŞAYLAN, Gencay (1986). Türkiye'de Kapitalizm, Bürokrasi ve Siyasal Ideoloji. Ankara: Verso Yay"nlar".

THOMPSON, James (1967). Organization in Action. New York: Mc-Graw Hill.

TOPF, Richard (1993). "Advice to Governments: Some theoratical and practical Issues" in Guy Peters and Anthony Barker (ed.) Advising West European Governments: Inquiries, Expertise and Public Policy. Edinburgh: Edinburgh University Press.pp.183-198.

TUTUM, Cahit (1968). "Türk Idaresinde Politik Nitelikte Yüksek Kademe Yoneticilik Mevkileri thdas Edilmeli midir? Genel Bir Değerlendirme" Amme Ilaresi Dergisi. 1:3-4, pp. 168-177.

(1976). "Yơnetimin Siyasallaşması ve Partizañlık", Amme.Idaresi Dergisi. 9:4. pp.9-32

(1990). "Kamu Personeli Sorunu", Amme Idaresi Dergisi. 23:3. pp.31-45

TÜRKIYE VE ORTA DOǦU AMME IDARESI ENSTITÜSü, Kamu Yönetimi Araştırması Genel Rapor, Ankara,1990.

Merkezi Hükümet Teşkilatı Araştırma Projesi Yönetim Kurulu Raporu. Ankara,1963. 
URWICK, Lyndall (1937). "Organization As a Technical Problem" in URWICK, Lyndall, L.GULICK. Papers on the Science of Administration. New York: Institute of Public Administration. pp.49-88.

URWICK, Lyndall and Ernest DALE (1960). Staff in Organization. New York: McGraw - Hill Book Company, Inc.

WELLER, Patrick (1987). "Types of Advice" in William Plowden, Advising the Rulers. Oxford: Basic Blackwell.

WILleTS, David (1987). "The Role of the Prime Minister's Policy Unit", Public Administration. 65:4. pp. 442-455. 